\title{
PENGAPLIKASIAN CERTAINTY FACTOR PADA SISTEM PAKAR UNTUK MENDIAGNOSA PENYAKIT CAMPAK RUBELLA
}

\author{
Sitti Zuhriyah ${ }^{1}$, Pujianti Wahyuningsih ${ }^{2}$

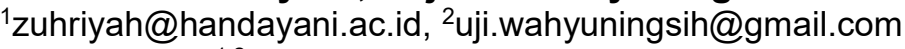 \\ 1,2STMIK Handayani Makassar
}

\begin{abstract}
Abstrak
Campak rubella merupakan $p$ enyakit yang dapat menyerang ibu hamil, balita, anak-anak, dan orang dewasa. Tujuan penelitian ini adalah penggunaan metode certainty factor pada aplikasi sistem pakar berbasis website untuk mendiagnosa penyakit campak rubella. Pemanfatan teknologi informasi pada aplikasi sistem pakar dapat membantu masyarakat dalam mendeteksi penyakit campak rubella sejak dini. Certainty factor merupakan salah satu metode yang dapat digunakan untuk menghadapi suatu permasalahan yang belum pasti jawabannya. Pada penelitian ini, metode certainty factor telah diaplikasikan pada aplikasi sistem pakar untuk mendiagnosa penyakit campak rubella berdasarkan gejala penyakit yang dirasakan oleh pasien. Hasil dari penelitian ini adalah sistem pakar berbasis website dapat memberikan informasi dan mendiagnosa gejala penyakit campak rubella sesuai dengan pertanyaan yang diajukan oleh sistem pakar dan gejala penyakit yang dirasakan oleh pasien.
\end{abstract}

Kata kunci: Certainty factor, Campak rubella, Sistem pakar.

\section{Abstract}

Rubella measles is a disease that can infect to the pregnant mothers, toddlers, children, and adults. The purpose of this study is applicate the certainty factor method to the expert system application based on website to diagnose the rubella measles disease. The utilization of information technology into the expert system application can help society to detect the rubella measles disease early. Certainty factor is one method that can be used to handle a problem that is uncertain the answer. In this study, the certainty factor method has been applied on expert system application to diagnose rubella measles based on symptoms of the disease felt by patients. The result of this study is an expert system based on the website can provide information and diagnose symptoms of rubella measles following the questions proposed by the system and symptoms of the disease felt by the patient.

Keywords: Certainty factor, Rubella measles, Expert system.

\section{Pendahuluan}

Penyakit campak rubella merupakan penyakit yang dapat menginfeksi ibu hamil [1][2][3], balita [1], anak-anak [1][2], remaja, dan orang dewasa [2][3]. Penyakit ini dapat menular dengan mudah melalui batuk dan bersin [3], sehingga bagi masyrakat awam yang belum memahami penyakit tersebut akan sangat mudah menular dan menginfeksi orang lain. Jika penyakit ini menginfeksi wanita yang hamil muda maka dapat menyebabkan terjadinya keguguran, kematian janin bahkan janin yang akan dilahirkan akan menderita penyakit cacat seumur hidup seperti sindrom rubella kongenital. Kecacatan ini bisa berupa katarak pada mata, tuli serta kelainan jantung [1][3].

Secara umum gejala penyakit campak rubella adalah ruam pada kulit, demam, sakit kepala, mata merah dan berair, sakit pada persendian, serta hilangnya nafsu makan [2][3], gejala-gejala tersebut dapat menyerang anak-anak, usia dewasa, dan ibu hamil. Infeksi rubella pada anak-anak ditandai dengan adanya ruam pada kulit disertai dengan sakit demam. Pada usia dewasa penyakit ini dapat ditandai dengan gejala sakit kepala, mata merah dan berair, sakit pada persendian dan nafsu makan hilang. Pada wanita hamil, gejala rubella ini muncul pada saat usia kehamilan kurang lebih 13 hingga 20 minggu, sehingga dapat berakibat abortus, kematian janin dan sindroma rubella kongeltial [2], serta dapat menjadikan bayi cacat tuli, kebutaan, cacat jantung, dan cacat intelektual [3].

Permasalahan yang dihadapi oleh masyarakat saat ini adalah kurangnya pemahaman dan pengetahuan mereka tentang gejala awal peyakit campak rubella. Salah satu solusi untuk menjawab permasalahan tersebut adalah dengan membangun sebuah sistem informasi pakar yang dapat membantu masyarakat dalam mendiagnosa penyakit campak rubella sejak dini. Tujuan penelitian ini adalah membangun sebuah sistem informasi pakar berbasis website untuk mendiagnosa penyakit campak rubella menggunakan metode certainty factor. Kelebihan metode certainty factor adalah dapat mengukur sebuah proses diagnosa dengan pasti atau tidah pasti [4] serta dapat digunakan untuk menghadapi suatu permasalahan yang belum pasti jawabannya [5]. Sistem informasi pakar 
ILKOM Jurnal Ilmiah Volume 11 Nomor 2 Agustus 2019 Terakreditasi peringkat 3 SK. No. 28/E/KPT/2019

yang dibangun pada penelitian ini dapat digunakan untuk mendiagnosa penyakit campak rubella pada anak, remaja, usia dewasa, dan ibu hamil dengan tingkat akurasi yang diharapkan dapat membantu masyarakat dalam mendiagnosa penyakit campak rubella sejak dini.

\section{Metode}

\subsection{Certainty Factor}

Certainty factor merupakan metode yang dapat digunakan untuk menghadapi suatu permasalahan yang belum pasti jawabannya. Ketidakpastian ini merupakan sebuah probabilitas karena hasilnya dapat berupa "mungkin" atau "hampir pasti" [5]. Pemanfaatan metode certainty factor pada aplikasi sistem pakar telah diaplikasikan untuk mendeteksi resiko osteoporosis dan osteoarthritis [5] mendiagnosa penyakit diabetes mellitus [6], mendiagnosa gejala demam [7], mendiagnosa jenis penyakit stroke [8], dan mendiagnosa penyakit ispa [9]. Pada penelitian ini, metode certainty factor digunakan untuk mendiagnosa penyakit campak rubella.

Langkah awal yang dilakukan oleh pakar adalah memasukkan pertanyaan diagnosa yang berhubungan dengan gejala penyakit campak rubella kemudian memasukkan nilai persentase $\mathrm{MB}$ (Measure Belief) dan MD (Measure Disbelief). Pada data MB terdapat nilai integrity dan ability, fungsi nilai integrity dan ability adalah untuk mengukur nilai tingkat kepercayaan dari MB. Pada data MD terdapat nilai benevolence dan satisfaction, fungsi nilai benevolence dan satisfaction adalah untuk mengukur nilai ketidakpercayaan dari MD. Semua data tersebut akan diproses menggunakan metode certainty factor sebanyak 3 langkah yaitu $\mathrm{CCF}_{1}$ untuk mengukur $\mathrm{MB}, \mathrm{CCF}_{2}$ untuk mengukur $\mathrm{MD}$, dan $\mathrm{CCF}_{3}$ untuk perhitungan hasil certainty factor $(\mathrm{CF})$. Berikut adalah flowchart certainty factor yang digunakan pada penelitian ini.
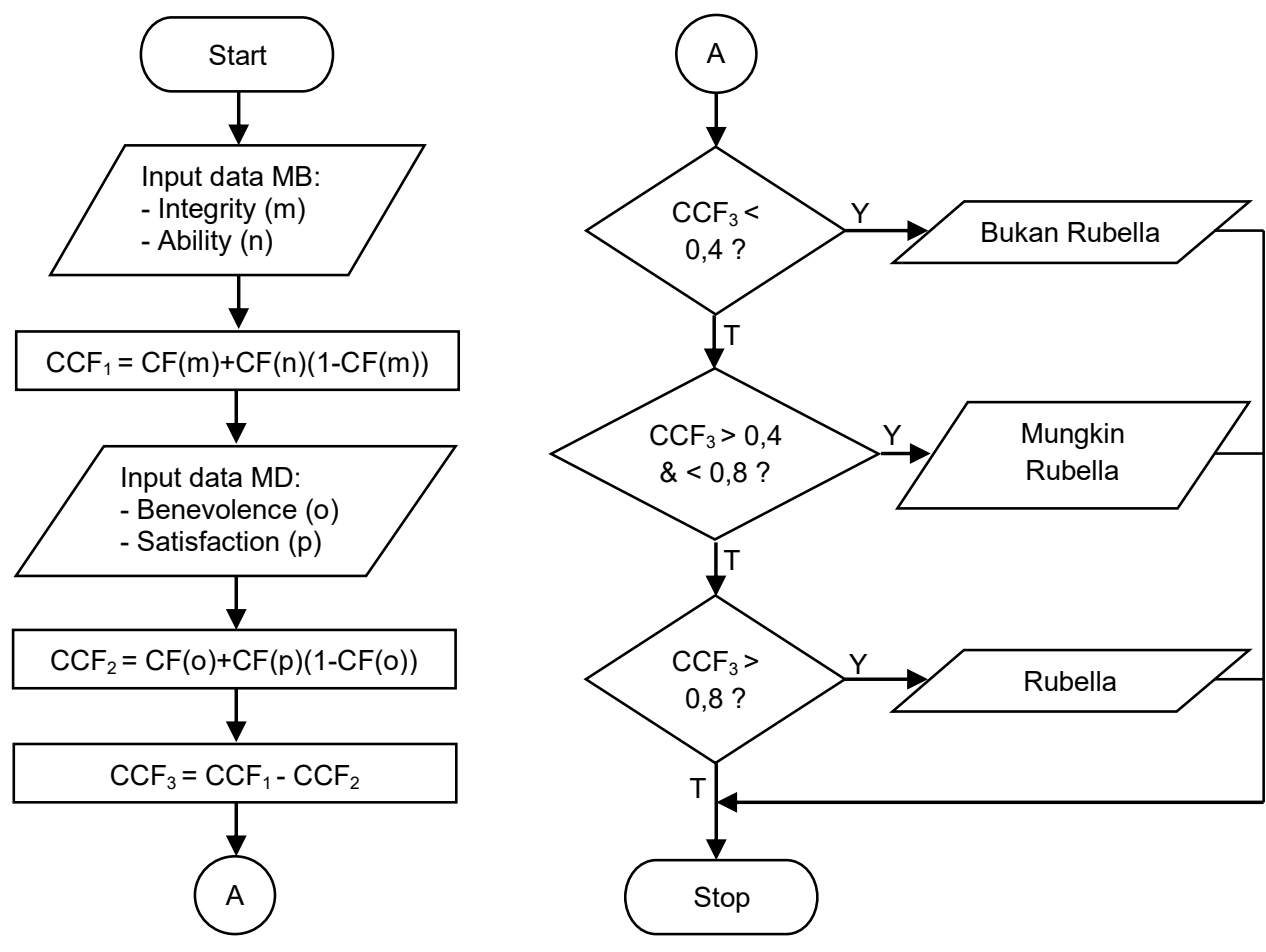

Gambar 1. Flowchart certainty factor

\subsection{Sistem Pakar}

Sistem pakar merupakan suatu model yang dirancang menggunakan program komputer untuk menyelesaikan suatu masalah dimana tingkat kemampuannya dalam menyelesaikan masalah setara dengan kemampuan seorang pakar atau dapat meniru kemampuan pakar [10]. Sistem pakar pada penelitian ini akan diaplikasikan pada sistem informasi berbasis website. Website adalah sebuah sistem dengan informasi yang disajikan dalam bentuk teks, gambar, suara dan lain-lain yang tersimpan dalam sebuah server web internet yang disajikan dalam bentuk hiperteks [11]. 
ILKOM Jurnal Ilmiah Volume 11 Nomor 2 Agustus 2019 Terakreditasi peringkat 3 SK. No. 28/E/KPT/2019

Pengaplikasian sistem pakar berbasis website telah diaplikasikan untuk mendiagnosa penyakit darah pada manusia [12], mendiagnosa dini penyakit tuberkulosis [13], dan mendiagnosa penyakit anak [14]. Sistem pakar berbasis website yang akan dibangun pada penelitian ini adalah mendiagnosa penyakit campak rubella dimana kemampuan diagnosa dari sistem informasi ini diharapkan dapat menyamai kemampuan seorang pakar dalam medeteksi penyakit campak rubella. Dibutuhkan data yang akurat dalam penelitian ini agar sistem informasi yang dibangun dapat menyamai level seorang pakar.

\subsection{Campak Rubella}

Penyakit campak rubella merupakan salah satu jenis penyakit yang berbahaya dan dapat menyerang siapa saja, seperti ibu hamil, anak-anak, dan orang dewasa. Dampaknya adalah dapat menyebabkan cacat seumur hidup bahkan kematian. Penyakit ini menyebabkan kelenjar bengkak, nyeri sendi dan ruam pada wajah dan leher yang berlangsung dua sampai tiga hari [3], gejala lainnya adalah ruam pada kulit disertai sakit demam, sakit kepala, mata merah dan berair, serta dapat menyebabkan hilangnya nafsu makan [2]. Pada penelitian ini, gejala-gejala penyakit campak rubella tersebut akan dimasukkan kedalam sistem dan digunakan sebagai bahan dasar untuk mendiagnosa penyakit campak rubella sejak dini.

\subsection{Sistem yang berjalan dan diusulkan}

Pada sistem yang berjalan, ketika pasien ingin melakukan konsultasi ke dokter maka pertama yang dilakukan adalah mengambil nomor antrian kepada admin puskesmas atau rumah sakit kemudian melakukan konsultasi ke dokter ahli. Dokter kemudian menanyakan gejala penyakit yang dirasakan oleh pasien, berdasarkan hasil dari pertanyaan tersebut kemudian dokter dapat memberikan kesimpulan diagnosa penyakit campak rubella yang diderita oleh pasien. Berdasarkan hasil kesimpulan diagnosa kemudian dokter memberikan resep obat kepada pasien untuk dibeli ke apotik, setelah itu pasien melakukan pembayaran dikasir untuk membayar biaya jasa konsultasi dan obat.

Sistem yang diusulkan pada penelitian ini adalah pasien atau masyarakat yang ingin mendiagnosa penyakitnya tidak perlu lagi datang ke puskesmas atau rumah sakit untuk berkonsultasi dengan dokter, namun pasien dapat mendiagnosa penyakitnya sendiri dengan cara mengakses website sistem pakar yang dibangun oleh peneliti. Pasien dapat mendiagnosa penyakitnya dengan cara menjawab pertanyaan-pertanyaan yang diajukan oleh sistem layaknya seorang dokter, kemudian setelah pasien menjawab semua pertanyaan maka sistem pakar dapat memberikan jawaban atau solusi dari gejala penyakit yang dirasakan oleh pasien. Berikut adalah gambar use case diagram pada sistem yang berjalan dan yang diusulkan.

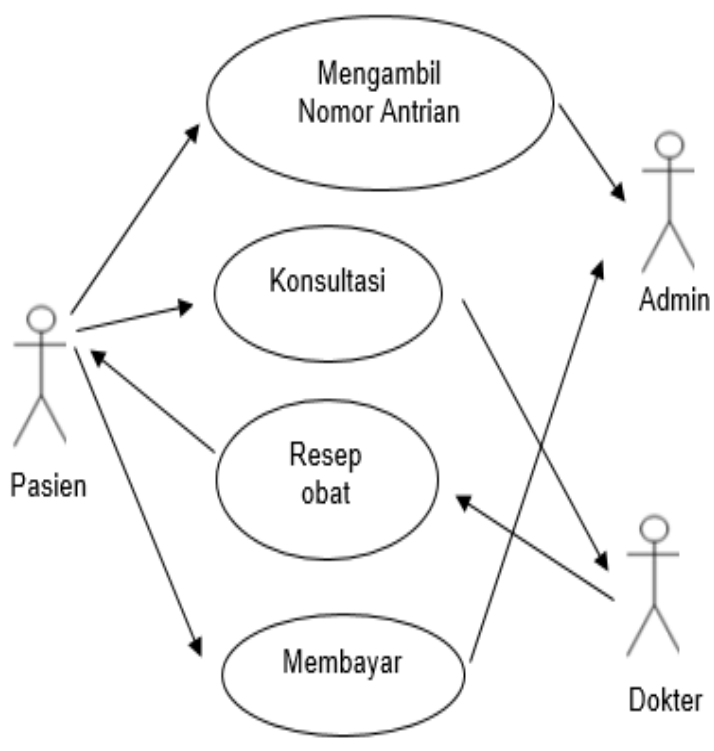

A

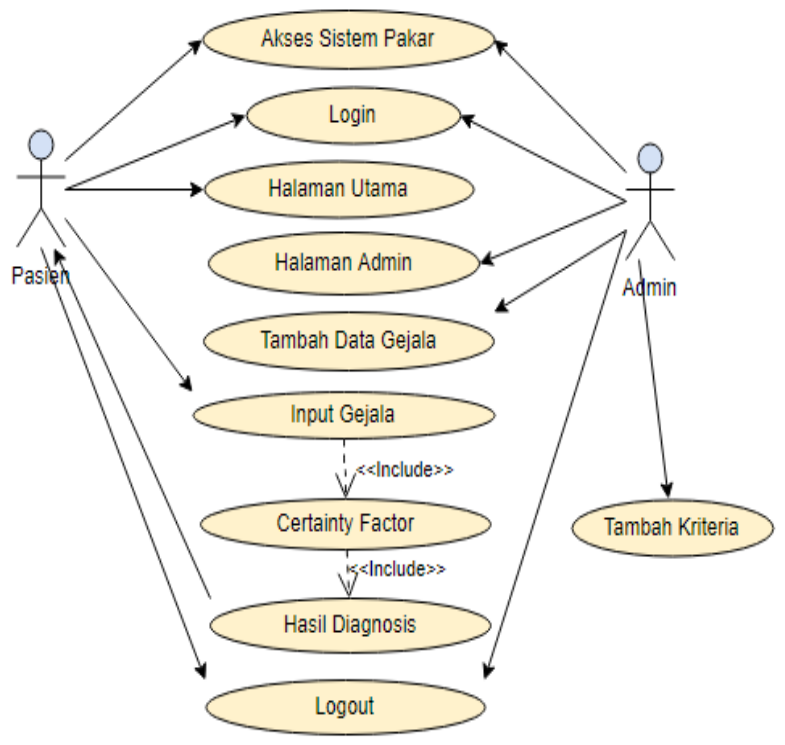

B

Gambar 2. Sistem yang berjalan (A); Sistem yang diusulkan (B) 
ILKOM Jurnal Ilmiah Volume 11 Nomor 2 Agustus 2019

Terakreditasi peringkat 3 SK. No. 28/E/KPT/2019

\section{Hasil dan Pembahasan}

Hasil dari penelitian ini adalah sistem pakar diagnosa penyakit campak rubella menggunakan metode certainty factor berbasis website. Langkah awal yang dilakukan pada sistem ini adalah pakar atau admin memasukkan informasi gejala penyakit dan semua pertanyaan terkait campak rubella bersama dengan persentase nilai MB dan MD. Fungsi nilai MB dan MD adalah untuk memberikan persentase kemungkinan gejala penyakit dari campak rubella. Tabel 1 memperlihatkan kode data, gejala penyakit, persentase nilai MB, dan persentase nilai MD yang digunakan untuk mendiagnosa penyakit campak rubella.

Tabel 1. Gejala penyakit campak rubella

\begin{tabular}{llcc}
\hline Kode & \multicolumn{1}{c}{ Gejala penyakit } & MB & MD \\
\hline G001 & Ruam merah yang bermula di wajah, lalu menyebar ke badan dan tungkai & 0,95 & 0,05 \\
G002 & Demam & 0,75 & 0,25 \\
G003 & Sakit Kepala & 0,75 & 0,25 \\
G004 & Pilek dan Hidung tersumbat & 0,60 & 0,40 \\
G005 & Tidak nafsu makan & 0,60 & 0,40 \\
G006 & Mata merah & 0,60 & 0,40 \\
G007 & Nyeri Sendi & 0,95 & 0,05 \\
G008 & Muncul benjolan sekitar telinga dan leher, akibat pembengkakan kelenjar & 0,95 & 0,05 \\
& getah bening & & \\
\hline
\end{tabular}

Pada penyakit campak rubella terdapat beberapa gejala penyakit utama yang dirasakan oleh pasien sehingga dapat didiagnosa sebagai penyakit campak rubella yaitu pembengkakan kelenjar getah bening, nyeri sendi, dan ruam pada wajah dan leher [2][3]. Gejala penyakit lain akan dirasakan oleh pasien ketika menderita penyakit campak rubella yaitu demam, sakit kepala, pilek dan hidung tersumbat, tidak ada nafsu makan, serta mata merah berair [2]. Pada sistem informasi yang dibangun, sistem dapat mendeteksi penyakit campak rubella ketika gejala penyakit utama dan pendukung dirasakan oleh pasien, ketika pasien hanya merasakan beberapa gejala saja dari gejala-gejala penyakit campak rubella maka dapat disimpulkan bahwa itu kemungkinan adalah gejala penyakit campak rubella atau bukan penyakit campak rubella. Pada tabel 2 memperlihatkan kode output dan hasil diagnosa berupa output yang akan ditampilkan pada saat pasien telah melakukan diagnosa penyakit campak rubella.

Tabel 2. Hasil diagnosa penyakit campak rubella

\begin{tabular}{cl}
\hline Kode & \multicolumn{1}{c}{ Hasil diagnosa } \\
\hline D01 & Rubella \\
D02 & Mungkin Rubella \\
D03 & Bukan Rubella \\
\hline
\end{tabular}

Pengaplikasian certainty factor pada penelitian ini dilakukan dengan cara memasukkan rumus dasar algoritma certainty factor berdasarkan flowchart yang telah dibangun pada gambar 1 . Adapun rumus dasar dari algoritma certainty factor (CF) yang digunakan pada peneltian ini adalah:

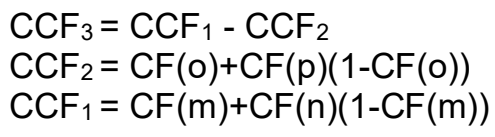

Dimana $\mathrm{CCF}_{3}$ adalah nilai akhir dari Certainty Factor, $\mathrm{CCF}_{2}$ adalah nilai hasil operasi untuk mencari nilai $\mathrm{MD}$, dan $\mathrm{CCF}_{1}$ adalah nilai hasil operasi untuk mencari nilai MB. Berdasarkan hasil perhitungan $\mathrm{CCF}_{3}$ dihasilkan sebuah angka yang dapat dijadikan sebagai keputusan diagnose dengan tingkat kepercayaan yang berbeda-beda. Berikut adalah tabel nilai tingkat kepercayaan berdasarkan hasil perhitungan dari $\mathrm{CCF}_{3}$.

Tabel 3. Tabel tingkat kepercayaan

\begin{tabular}{lc}
\hline \multicolumn{1}{c}{ Certainty Term } & CF \\
\hline Bukan Rubella & $<0,4$ \\
Mungkin Rubella & $>=0,4$ and $<0,8$ \\
Rubella & $>=0,8$ \\
\hline
\end{tabular}


ILKOM Jurnal Ilmiah Volume 11 Nomor 2 Agustus 2019

Terakreditasi peringkat 3 SK. No. 28/E/KPT/2019

Berdasarkan kode gejala penyakit, kode hasil diagnosa, dan tingkat kepercayaan yang telah dibangun, maka untuk menentukan hasil diagnose terdapat rule yang digunakan sehingga menghasilkan angka tingkat kepercayaan dan output diagnosa. Pada tabel 4 memperlihatkan rule yang digunakan untuk mendiagnosa penyakit campak rubella sesuai dengan gejala penyakit dan output yang dihasilkan.

Tabel 4. Rule deteksi gejala penyakit

\begin{tabular}{clcc}
\hline No & \multicolumn{1}{c}{ Rule } & CF & Hasil Analisa \\
\hline $\mathbf{1}$ & IF G001 AND G002 AND G003 AND G004 AND G005 & 1 & Rubella \\
& AND G006 AND G007 AND G008 THEN D01 & & Rubella \\
$\mathbf{2}$ & $\begin{array}{l}\text { IF G001 AND G002 AND G003 AND G004 AND G006 } \\
\text { AND G007 AND G008 THEN D01 }\end{array}$ & 0,9 & Rubella \\
$\mathbf{3}$ & $\begin{array}{l}\text { IF G001 AND G002 AND G003 AND G004 AND G005 } \\
\text { AND G007 AND G008 THEN D01 }\end{array}$ & 0,9 & Mungkin rubella \\
$\mathbf{4}$ & $\begin{array}{l}\text { IF G001 AND G002 AND G003 AND G006 AND G007 } \\
\text { AND G008 THEN D02 }\end{array}$ & 0,7 & Mungkin rubella \\
$\mathbf{5}$ & $\begin{array}{l}\text { IF G001 AND G002 AND G003 AND G004 AND G007 } \\
\text { AND G008 THEN D02 }\end{array}$ & 0,7 & Mungkin rubella \\
$\mathbf{6}$ & $\begin{array}{l}\text { IF G001 AND G002 AND G005 AND G006 AND G007 } \\
\text { AND G008 THEN D02 }\end{array}$ & 0,6 & Mungkin rubella \\
$\mathbf{7}$ & $\begin{array}{l}\text { IF G001 AND G003 AND G004 AND G006 AND G007 } \\
\text { AND G008 THEN D02 }\end{array}$ & 0,6 & Mungkin rubella \\
$\mathbf{8}$ & IF G001 AND G004 AND G005 AND G006 AND G007 & 0,5 & Mungkin rubella \\
$\mathbf{9}$ & $\begin{array}{l}\text { AND G008 THEN D02 } \\
\text { IF G001 AND G002 AND G003 AND G007 AND G008 }\end{array}$ & 0,5 & Bukan rubella \\
$\mathbf{1 0}$ & THEN D02 & & \\
$\mathbf{1 1}$ & THEN G002 AND G003 AND G004 AND G005 AND G006 & 0,3 & Bukan rubella \\
$\mathbf{1 2}$ & IF G002 AND G003 AND G004 THEN D03 & & Bukan rubella \\
\hline
\end{tabular}

Dalam pengaplikasiannya, pasien dapat mendiagnosa penyakitnya dengan cara mengakses website sistem pakar diagnosa penyakit campak rubella secara online. Pada penelitian ini telah dilakukan uji coba terhadap beberapa pasien untuk mendiagnosa penyakit campak rubella. Berikut adalah tabel ujicoba sistem pakar menggunakan metode certainty factor terhadap pasien.

Tabel 5. Ujicoba sistem terhadap pasien

\begin{tabular}{|c|c|c|c|c|}
\hline Pasien & Gejala Penyakit & Kondisi & Kepercayaan & Hasil Analisa \\
\hline \multirow{8}{*}{ Pasien 1} & Ruam merah yang bermula di wajah, lalu & $\mathrm{Ya}$ & \multirow{8}{*}{1} & \multirow{8}{*}{ Rubella } \\
\hline & Demam & Ya & & \\
\hline & Sakit Kepala & $\mathrm{Ya}$ & & \\
\hline & Pilek dan Hidung tersumbat & Ya & & \\
\hline & Tidak nafsu makan & Ya & & \\
\hline & Mata merah & Ya & & \\
\hline & Nyeri Sendi & Ya & & \\
\hline & $\begin{array}{l}\text { Muncul benjolan sekitar telinga dan leher, } \\
\text { akibat pembengkakan kelenjar getah bening }\end{array}$ & Ya & & \\
\hline \multirow{8}{*}{ Pasien 2} & $\begin{array}{l}\text { Ruam merah yang bermula di wajah, lalu } \\
\text { menyebar ke badan dan tungkai }\end{array}$ & Ya & \multirow{8}{*}{0,7} & \multirow{8}{*}{$\begin{array}{l}\text { Mungkin } \\
\text { Rubella }\end{array}$} \\
\hline & Demam & Ya & & \\
\hline & Sakit Kepala & $\mathrm{Ya}$ & & \\
\hline & Pilek dan Hidung tersumbat & Ya & & \\
\hline & Tidak nafsu makan & Tidak & & \\
\hline & Mata merah & Tidak & & \\
\hline & Nyeri Sendi & Ya & & \\
\hline & $\begin{array}{l}\text { Muncul benjolan sekitar telinga dan leher, } \\
\text { akibat pembengkakan kelenjar getah bening }\end{array}$ & Ya & & \\
\hline
\end{tabular}


ILKOM Jurnal Ilmiah Volume 11 Nomor 2 Agustus 2019

Terakreditasi peringkat 3 SK. No. 28/E/KPT/2019

\begin{tabular}{|c|c|c|c|c|}
\hline Pasien & Gejala Penyakit & Kondisi & Kepercayaan & Hasil Analisa \\
\hline \multirow{8}{*}{ Pasien 3} & $\begin{array}{l}\text { Ruam merah yang bermula di wajah, lalu } \\
\text { menyebar ke badan dan tungkai }\end{array}$ & Ya & \multirow{8}{*}{0,5} & \multirow{8}{*}{$\begin{array}{l}\text { Mungkin } \\
\text { Rubella }\end{array}$} \\
\hline & Demam & Ya & & \\
\hline & Sakit Kepala & Ya & & \\
\hline & Pilek dan Hidung tersumbat & Tidak & & \\
\hline & Tidak nafsu makan & Tidak & & \\
\hline & Mata merah & Tidak & & \\
\hline & Nyeri Sendi & $\mathrm{Ya}$ & & \\
\hline & $\begin{array}{l}\text { Muncul benjolan sekitar telinga dan leher, } \\
\text { akibat pembengkakan kelenjar getah bening }\end{array}$ & Ya & & \\
\hline \multirow{8}{*}{ Pasien 4} & $\begin{array}{l}\text { Ruam merah yang bermula di wajah, lalu } \\
\text { menyebar ke badan dan tungkai }\end{array}$ & Tidak & \multirow{8}{*}{0,2} & \multirow{8}{*}{$\begin{array}{l}\text { Bukan } \\
\text { Rubella }\end{array}$} \\
\hline & Demam & Ya & & \\
\hline & Sakit Kepala & Ya & & \\
\hline & Pilek dan Hidung tersumbat & Ya & & \\
\hline & Tidak nafsu makan & Tidak & & \\
\hline & Mata merah & Tidak & & \\
\hline & Nyeri Sendi & Tidak & & \\
\hline & $\begin{array}{l}\text { Muncul benjolan sekitar telinga dan leher, } \\
\text { akibat pembengkakan kelenjar getah bening }\end{array}$ & Tidak & & \\
\hline \multirow{8}{*}{ Pasien 5} & $\begin{array}{l}\text { Ruam merah yang bermula di wajah, lalu } \\
\text { menyebar ke badan dan tungkai }\end{array}$ & Tidak & \multirow{8}{*}{0,2} & \multirow{8}{*}{$\begin{array}{l}\text { Bukan } \\
\text { Rubella }\end{array}$} \\
\hline & Demam & Tidak & & \\
\hline & Sakit Kepala & Tidak & & \\
\hline & Pilek dan Hidung tersumbat & $\mathrm{Ya}$ & & \\
\hline & Tidak nafsu makan & Ya & & \\
\hline & Mata merah & Ya & & \\
\hline & Nyeri Sendi & Tidak & & \\
\hline & $\begin{array}{l}\text { Muncul benjolan sekitar telinga dan leher, } \\
\text { akibat pembengkakan kelenjar getah bening }\end{array}$ & Tidak & & \\
\hline
\end{tabular}

Sistem yang telah dibangun dapat diakses oleh pakar dan pasien secara online melalui laman website. Pakar dapat menginput informasi gejala, tingkat kepercayaan, dan sebagainya, sedangkan pasien hanya dapat mengakses website untuk mendiagnosa penyakitnya. Berdasarkan hasil yang telah dibangun, berikut adalah tampilan gambar dari sistem informasi diagnosa penyakit campak rubella menggunakan metode certainty factor.

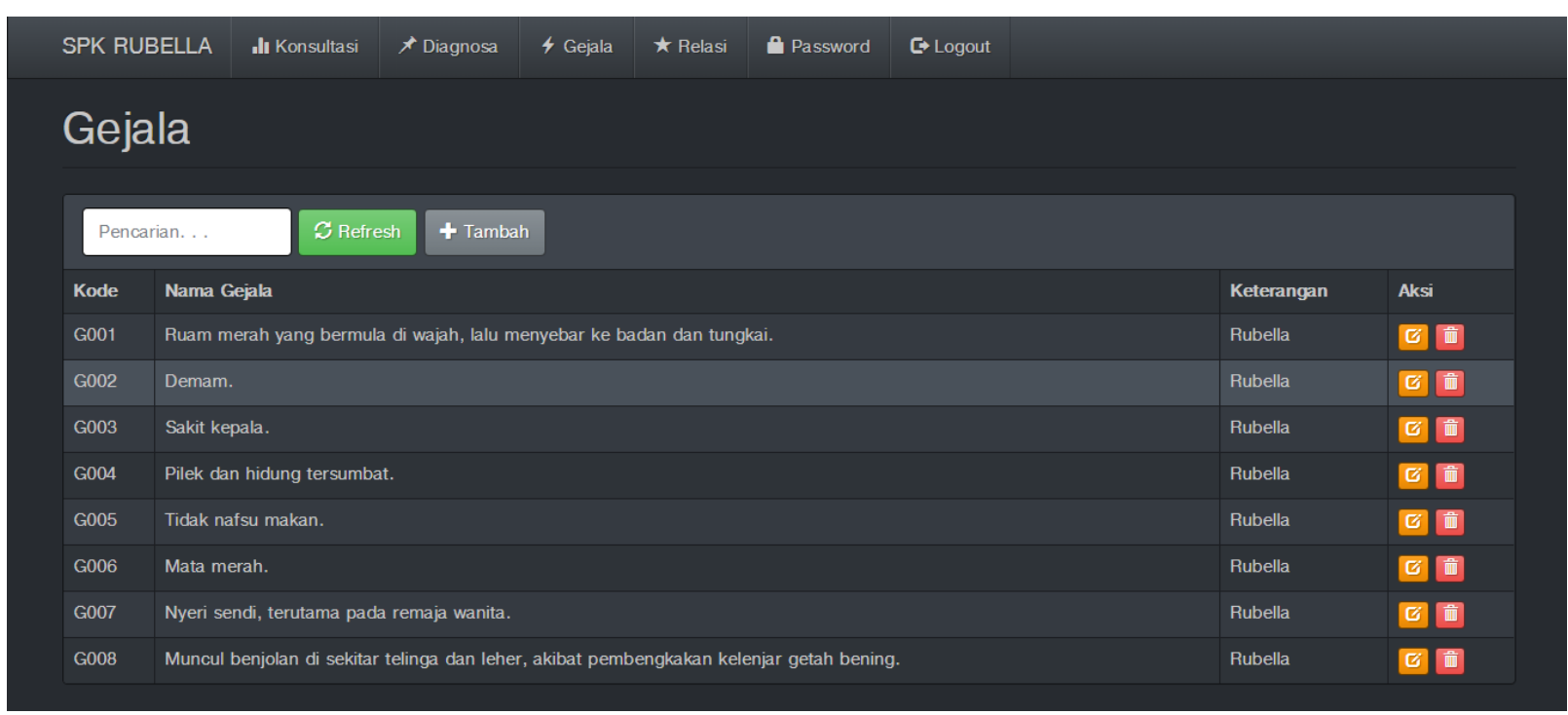

Gambar 3. Form input kode gejala dan gejala penyakit 
ILKOM Jurnal IImiah Volume 11 Nomor 2 Agustus 2019

Terakreditasi peringkat 3 SK. No. 28/E/KPT/2019

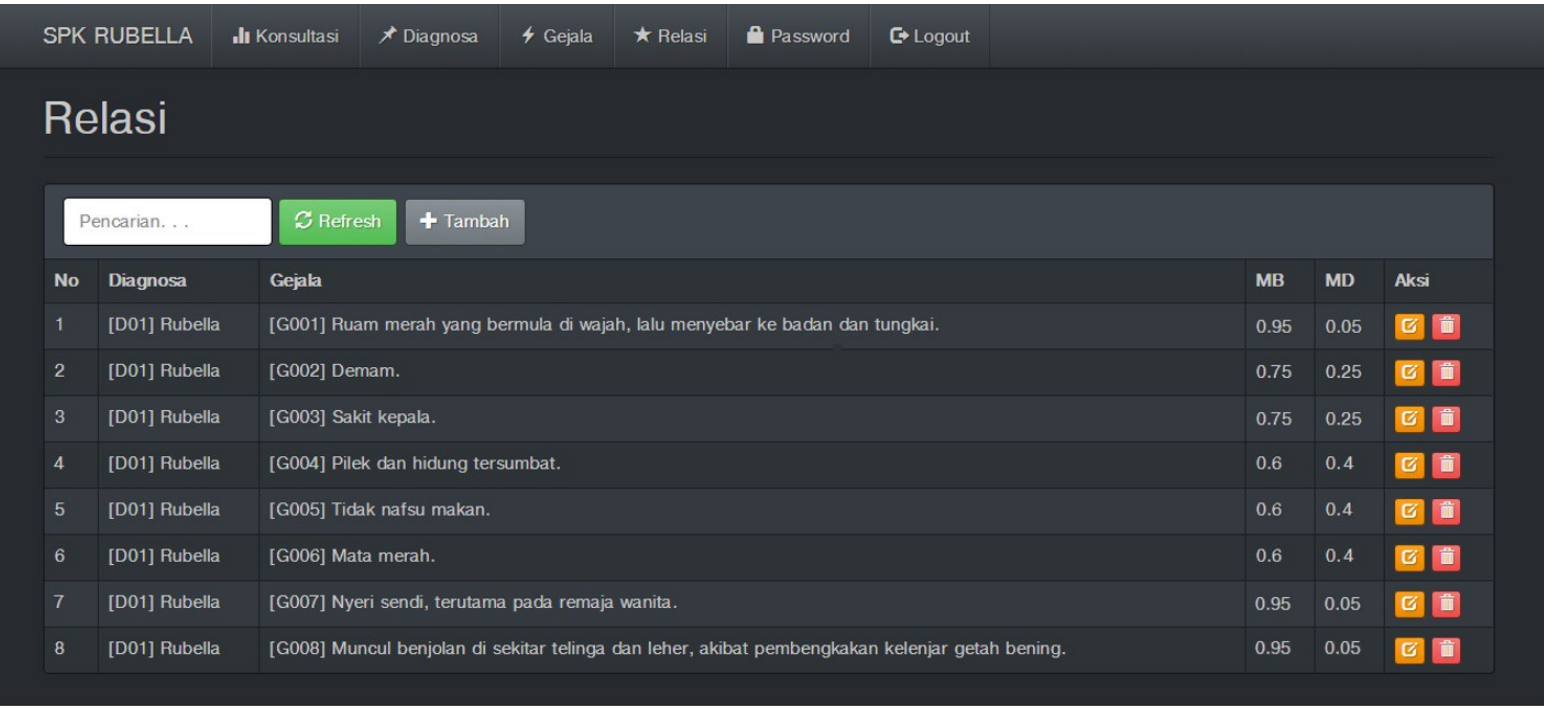

Gambar 4. Form relasi antara gejala dengan nilai MB dan MD

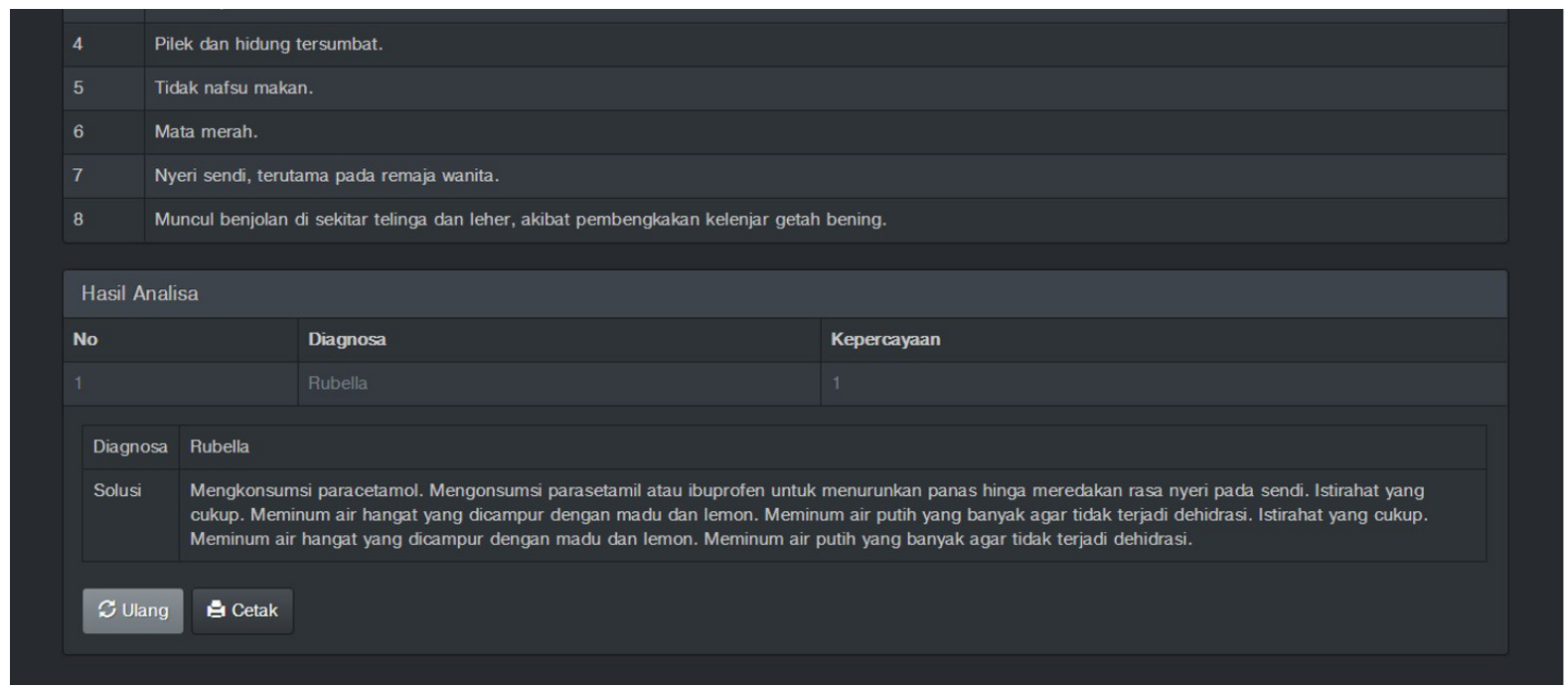

Gambar 4. Form hasil diagnosa

$5 / 30 / 2019$

Cetak Laporan

Hasil Diagnosa Sistem Pakar Penyakit Rubella

Gejala Terpilih

\begin{tabular}{|l|l|}
\hline No & \multicolumn{1}{|c|}{ Nama Gejala } \\
\hline 1 & Ruam merah yang bermula di wajah, lalu menyebar ke badan dan tungkai. \\
\hline 2 & Demam. \\
\hline 3 & Sakit kepala. \\
\hline 4 & Pilek dan hidung tersumbat. \\
\hline 5 & Tidak nafsu makan. \\
\hline 6 & Mata merah. \\
\hline 7 & Nyeri sendi, terutama pada remaja wanita. \\
\hline 8 & Muncul benjolan di sekitar telinga dan leher, akibat pembengkakan kelenjar getah bening. \\
\hline
\end{tabular}

Hasil Analisa

\section{No Diagnosa Kepercayaan \\ \begin{tabular}{|l|l|l|}
\hline 1 & Rubella & 1 \\
\hline
\end{tabular}}

\begin{tabular}{|l|l|l|l}
\hline Diagnosa & Rubella \\
\hline
\end{tabular}

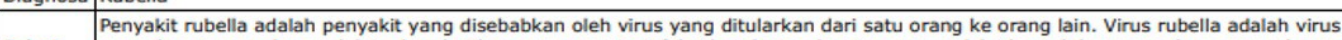

Solusi $\quad$ yang dapat menyebar melalui udara ketika orang yang terinfeksi batuk atau bersin, atau melalui kontak langsung dengan peralatan yang digunakan penderita seperti alat bantu pernafasan bahkan hanya sekadar sentuhan.

Gambar 5. Form cetak laporan

DOI: http://dx.doi.org/10.33096/ilkom.v11i2.441.159-166

ILKOM Jurnal IImiah work is licensed under a CCA-SA 4.0 International License. | 165 


\section{Kesimpulan dan Saran}

Pengaplikasian metode certainty factor pada sistem pakar berbasis website untuk mendiagnosa penyakit campak rubella telah diaplikasikan pada penelitian ini. Nilai Certainty Factor (CF) didapatkan berdasarkan hasil perhitungan dari persentase nilai Measure Belief (BM) dan Measure Disbelief (MD). Metode certainty factor yang diaplikasikan dapat dengan baik digunakan untuk mendiagnosa penyakit campak rubella sesuai dengan pertanyaan yang diajukan oleh sistem pakar dan jawaban yang dipilih oleh pasien dengan tingkat kepercayaan antara 0,2 hingga 1 . Jika nilai $C F<0,4$ maka hasilnya adalah bukan rubella, jika nilai $\mathrm{CF}$ antara $>=0,4$ dan $<0,8$ maka hasilnya adalah mungkin campak rubella, sedangkan jika nilai CF $>=0,8$ maka sistem memberikan informasi bahwa pasien terdiagnosa penyakit campak rubella. Saran untuk penelitian kedepannya adalah sistem pakar yang dibangun bukan hanya dapat diakses melalui website namun juga dapat diakses melalui aplikasi mobile atau aplikasi smartphone.

\section{Ucapan Terima Kasih}

Terima kasih kami haturkan kepada KEMENRISTEK DIKTI yang telah memberikan support dan bantuan serta dukungan dari STMIK Handayani Makassar sehingga Penelitian Dosen Pemula (PDP) yang di amanahkan kepada kami dapat diselesaikan dengan baik.

\section{Daftar Pustaka}

[1] S. Handayani, B. Heriyanto, G. Wahyuhono, Susilowati, dan Subangkit, "Imunitas Terhadap Rubela Pada Balita dan Wanita Usia Subur di Kota Surabaya dan Kabupaten Tabanan," Bul. Penel. Kesehatan, Vol. 36, No. 2, 2008.

[2] AT. Hardiana, AS. Raksanagara, RTD. Judistiani, D. Widhiastuti, NS. Bachtiar, "Analisis Penyebaran dan Genotipe Rubela di Jawa Barat Tahun 2011-2013," Jurnal Farmasi Klinik Indonesia, Maret 2015, Vol. 4 No. 1, hIm 1-7, ISSN: 2252-6218, DOI: 10.15416/ijcp.2015.4.1.1

[3] Immunise Australia Program, "Campak, gondok, dan rubella," Diterbitkan oleh Pemerintah Victoria, 1 Treasury Place, Melbourne. Negara Bagian Victoria, Department of Health and Human Services, Januari 2016.

[4] K. E. Setyaputi, A. Fadlil, dan Sunardi, "Analisis Metode Certainty Factor Pada Sistem Pakar Diagnosa Penyakit THT," Jurnal Teknik Elektro, Vol. 10, No. 1, 2018

[5] S. Halim dan S. Hansun, "Penerapan Metode Certainty Factor dalam Sistem Pakar Pendeteksi Resiko Osteoporosis dan Osteoarthritis", ULTIMA Computing, vol. 7, no. 2, 2015.

[6] A. Riadi, "Penerapan Metode Certainty Factor Untuk Sistem Pakar Diagnosa Penyakit Diabetes Melitus Pada RSUD Bumi Panua Kabupaten Pohuwato," ILKOM Jurnal IImiah, Volume 9, Nomor 3, Desember 2017.

[7] Daniel dan Gloria Virginia, "Implementasi Sistem Pakar Untuk Mendiagnosa Penyakit Dengan Gejala Demam Menggunakan Metode Certainty Factor", Jurnal Informatika, vol. 6, no. 1, 2010.

[8] P. Wijayanti dan A. Fadlil, "Sistem Pakar Mendiagnosa Jenis Penyakit Stroke Menggunakan Metode Certainty Factor," Jurnal Sarjana Teknik Informatika, Volume 2 Nomor 1, Februari 2014.

[9] L. Septiana, "Perancangan Sistem Pakar Diagnosa Penyakit Ispa Dengan Metode Certainty Factor Berbasis Android," Jurnal Techno Nusa Mandiri Vol. XIII, No. 2 September 2016.

[10] Merlina, Nita, dan R. Hidayat, "Perancangan Sistem Pakar", Ghalia Indonesia. Yogyakarta, 2012.

[11] Simarmata, Janner, "Rekayasa Web", Yogyakarta: Andi offset, 2010.

[12] M. Silmi, Eko A. Sarwoko, dan K. Kushartantya, "Sistem Pakar Berbasis Web Dan Mobile Web Untuk Mendiagnosis Penyakit Darah Pada Manusia Dengan Menggunakan Metode Inferensi Forward Chaining", Jurnal Masyarakat Informatika, vol. 4, no. 7, 2013.

[13] W. Supartini, dan Hindarto, "Sistem Pakar Berbasis Web Dengan Metode Forward Chaining Dalam Mendiagnosis Dini Penyakit Tuberkulosis di JawaTimur," KINETIK Vol. 1, No. 3, November 2016: 147-154.

[14] Yuhandri, dan R. Winiarti, "Pembuatan Sistem Pakar Berbasis Web Untuk Mendiagnosa Penyakit Anak," Jurnal KomTekInfo Fakultas Ilmu Komputer, Volume 1, No. 2, Desember 2014. 